\title{
Z ZAGADNIEŃ LEKSYKOGRAFII POLSKO-CHIŃSKIEJ
}

\author{
Stownik to cierpliwy i nieznużony doradca, \\ towarzysz ksztatcenia sie $i$ kulturalnego życia, \\ kulturalnego obcowania zjakimkolwiek jezykiem¹.
}

Leksykografia zajmuje się teorią i praktyką tworzenia słowników, techniką układania informacji w taki sposób, aby dostęp do nich był łatwy i wygodny. Odwołując się do etymologii (greckie lexikón 'słownik' i gráphō 'piszę'), można ją zdefiniować po prostu jako naukę o pisaniu słowników. Aktualnie, w dobie Internetu, nowych mediów i komputeryzacji znaczenie tego pojęcia znacznie się poszerzyło - nie odnosi się ono już jedynie do tradycyjnych opracowań papierowych, ale również do pozycji online, programów komputerowych oraz aplikacji na urządzenia mobilne.

Uważa się, że leksykografia dwujęzyczna odgrywa szczególną rolę w komunikacji międzyjęzykowej, jest jednym z podstawowych elementów nauki języka obcego i korzystnie wpływa na rozwój kompetencji komunikacyjnej ${ }^{2}$. Z badań związanych z preferencjami dotyczącymi słowników wynika, że użytkownik, mając do wyboru dwa typy słowników (jedno- i dwujęzyczne), mimo uznania tych pierwszych za lepsze, chętniej decyduje się na skorzystanie z pozycji bilingwalnych ${ }^{3}$. Wykorzystywane sa one nie tylko w nauczaniu, ale również w translatoryce, handlu czy sektorze IT i staja się swoistym kompendium wiedzy na temat możliwości w zakresie ekwiwalencji ${ }^{4}$.

Liczba i objętość słowników dwujęzycznych w danej parze językowej jest uzależniona przede wszystkim od zapotrzebowania ich potencjalnych użytkowników, poziomu reprezentowanego przez dyscyplinę (w tym przypadku filologie) w kraju, jak również wzajemnych stosunków politycznych, społecznych, dyplomatycznych i kulturowych pomiędzy państwami, w których dane języki obowiązuja. Relacje polsko-chińskie intensyfikują się, czego dowodem mogą być m.in. liczne porozumienia o współpracy i umowy, np. o strategicznym partnerstwie czy o współpracy

1 S. Urbańczyk, Stowniki - ich rodzaje i usyyteczność, Wrocław - Warszawa - Kraków 1967, s. 3.

2 T. Piotrowski, Z zagadnień leksykografii, Warszawa 1994, s. 156-157.

3 A. Grzeszak, Jak koraystaja ze stownikón studenci małych filologii? „Linguodidactica” 2015, t. 19 , s. 65 .

4 H. Bartwicka, Archaizmy a leksykografia dwujezyczna (na praykktadz̧ie stownikón polsko-rosyjskich), „Zeszyty Naukowe Wyższej Szkoły Pedagogicznej w Bydgoszczy. Studia Filologiczne. Filologia Rosyjska" 1986, z. 27, s. 31. 
w dziedzinie turystyki. Szczególnie ważna z punktu widzenia naukowego kręgu sinologicznego jest umowa o wzajemnym uznawaniu dyplomów ukończenia studiów i tytułów zawodowych w szkolnictwie wyższym, ale nie mniej istotne są kwestie związane z gospodarka, jak uwzględnienie Polski na trasie Nowego Jedwabnego Szlaku, jak również swoisty boom na sinologię, nauki związane z Azją i biznes z Chinami. Rezultatem wzmożonej współpracy jest coraz większa liczba słowników polsko-chińskich i chińsko-polskich, które w ostatnich latach ukazały się w Polsce. Jednak wielu studentów oraz tłumaczy skłania się do korzystania z pozycji jedno- i dwujęzycznych chińsko-angielskich i angielsko-chińskich. Opracowania te mają bowiem dłuższą tradycję, są zdecydowanie obszerniejsze, a język angielski jest traktowany w dzisiejszym świecie jako pewnego rodzaju lingua franca. Najpopularniejszymi pozycjami wśród studentów sinologii są więc przede wszystkim słowniki anglojęzyczne ${ }^{5}$. Obserwuje się także odejście od tradycyjnych wydań książkowych i znaczny wzrost zainteresowania słownikami w formie aplikacji na telefon, pozycjami online i offline, jak również korpusami jedno- i dwujęzycznymi. Z przeprowadzonych w 2017 r. badań wynika, że spośród losowo wybranej grupy 50 studentów sinologii w Polsce i polonistyki w Chinach zaledwie 16\% badanych sięga po pozycje papierowe ${ }^{6}$. Warto zatem zastanowić się, czy leksykografia polsko-chińska spełnia oczekiwania odbiorców, jakiego rodzaju pozycje możemy znaleźć na rynku polskim i jakie informacje powinien zawierać dobry słownik.

Warto na początku omówić problemy, które moga pojawić się przy tworzeniu słownika w parze językowej język polski - język chiński. Przede wszystkim należy podkreślić, że języki te wywodzą się z dwóch różnych rodzin, a ich systemy są zróżnicowane praktycznie pod każdym względem, w tym leksykalno-semantycznym, co jest najistotniejsze $z$ punktu widzenia leksykografii. Już na początku stawia to leksykografa przed problemem wyboru rodzaju tworzonego słownika - czy będzie to słownik znaków (字典 - qiidiǎn), czy też słownik wyrazów (词典 - cídiān). W języku chińskim pojedynczy znak może być zarówno morfemem leksykalnym, jak i słowotwórczym, stanowić wyraz jednosylabowy, jak również wchodzić w relacje z innymi znakami, tworzyć wyrazy o wielosylabowej strukturze i różnorodnym znaczeniu'. Trudna jest zatem decyzja związana zarówno z typem słownika, jak i doborem haseł słownikowych.

\footnotetext{
5 Pisze o tym m.in. M. Achinger, Nowoczesne metody tworzenia stowników polsko-chinskich i chinsko-polskich, praca magisterska napisana pod kierunkiem prof. Zhao Ganga, Beijing Foreign Studies University, 2017, s. 28. Potwierdzają to również moje obserwacje i doświadczenia.

6 Ibidem, s. 29.

7 K. Rum, System pisma jako dodatkowe obciażenie kognitywne w nauce jezylka chińskiego [w:] Kognitywne obciażenia w nauce jezylka chińskiego. Materiały pokonferencyjne (VI Międzynarodowa Konferencja Edukacyjna Ustroń/Gliwice 2011, Ustroń/Gliwice 2011, s. 2, http://www.2011.konferencje-spnjo.polsl.pl/download/rum-k-kognitywne-obciazenia-w-nauce-jezyka-chinskiego.pdf (dostęp: 20.05.2018).
} 
Kwestią wielce kłopotliwą pozostaje również brak całkowicie korespondujących ekwiwalentów między tymi językami. Nawet tak powszednie i standardowe dla rodzimego użytkownika polskie słowo, jak 'babcia', nie ma swojego odpowiednika w języku chińskim. Dodatkowo słownik tego rodzaju ma być zestawieniem języków dwóch odmiennych kultur - z jednej strony chińskiej, wysokokontekstowej, czyli z pośrednim intuicyjnym stylem komunikacji, nielinearnym myśleniem oraz systemem norm społecznych mającym podstawy w filozofii konfucjańskiej, w której większość elementów językowych jest silnie nacechowana kulturowo, z drugiej strony polskiej - europejskiej, leżącej na granicy kultur wysokokontekstowych i niskokontekstowych, z dość bezpośrednim, jednoznacznym i konkretnym stylem komunikacji oraz silnym oddziaływaniem chrześcijaństwa na tożsamość narodowa. Podanie polskiego odpowiednika przy chińskim wyrazie, jak np. 'majster' w miejsce chiń. 师傅 (shifu) czy 'znajomości’ w miejsce chiń. 关系 (guānxi), może nie być satysfakcjonujące dla uczącego się, tłumacza czy innego użytkownika danego słownika, co więcej, może prowadzić do błędnego przyswojenia danego słowa i nieporozumień wynikających z jego użycia. Dlatego należy mieć na uwadze, jak wielka trudnością jest opracowywanie haseł i podjęcie właściwej decyzji w kwestii przyjęcia pewnych strategii przy tworzeniu słownika. Warto również wspomnieć o roli tego typu opracowań w odniesieniu do przekładu - tłumacz przekłada teksty jako całość, nie tłumaczy pojedynczych jednostek, wychodzi poza pojęcia i odpowiedniki znajdujące się w słowniku. W związku z tym, jeśli chodzi o ekwiwalencję, opracowania tego typu są często niezadowalające. $\mathrm{Na}$ tym właśnie polega paradoks - z jednej strony słowniki to mocno zorientowane na system języka kompendia leksykalne, z drugiej - rzadko znajduja zastosowanie w realnej komunikacji.

W dalszej części artykułu podejmę próbę zwięzłej analizy i oceny dostępnych na rynku dwujęzycznych słowników opracowanych w parze językowej język polski - język chiński z uwzględnieniem liczby haseł, przykładów użycia wyrazów we frazach lub zdaniach, ewentualnych definicji i informacji gramatycznej, prezentacji graficznej i czytelności oraz ogólnej użyteczności. Spróbuję również wskazać mocne strony każdego z nich oraz omówić kwestie, które wymagałyby udoskonalenia. Materiał zostanie zaprezentowany w układzie problemowym niechronologicznym. W celu analizy i zobrazowania sposobu tworzenia haseł poszczególnych słowników do większości omawianych pozycji dołączyłam przykłady fragmentów opracowań.

W porównaniu do oferty leksykograficznej w zakresie języków europejskich wybór polsko-chińskich i chińsko-polskich pozycji słownikowych jest bardzo ograniczony. Do roku 2018 na rynku ukazało się dwanaście publikacji leksykograficznych stworzonych w tej parze językowej ${ }^{8}$. Najstarszą z nich jest Zwiezły słownik inżynieryjno-budowlany opublikowany w 1959 r. przez Ministerstwo Inżynierii Budowlanej Chiń-

8 Do zestawienia nie wliczyłam słownika śląsko-chińskiego/ chińsko-śląskiego i kaszubsko-chińskiego/ chińsko-kaszubskiego. 
skiej Republiki Ludowej, niestety niedostępny w polskich zasobach bibliotecznych ani w sprzedaży, dlatego też nie można poddać go dokładnemu opisowi i analizie. Mimo to warto o nim wspomnieć jako ciekawostce leksykograficznej i pierwszej pozycji opracowanej w tej parze językowej.

Dopiero 31 lat później (w 1990 r.) pojawiło się kolejne opracowanie - Mały stownik polsko-chiński autorstwa Tadeusza Jeromina i Din Weia'. Słownik ten zawiera ponad 5 tysięcy haseł i, jak czytamy w przedmowie, przeznaczony jest zarówno (i przede wszystkim) dla poznających język polski Chińczyków, jak i dla zainteresowanych językiem chińskim Polaków. Słownik został opracowany w układzie alfabetycznym, a hasła oprócz terminu polskiego, chińskiego ekwiwalentu i transkrypcji pinyin zawierają obszerne objaśnienie gramatyczne dotyczące polskich wyrazów od rodzaju, liczby i przypadków przy rzeczownikach, poprzez formy, kwestie fleksyjne, aż po aspekt przy czasownikach $i$ wyjaśnienia dotyczące sposobu wymawiania trudnych wyrazów:

faun/a (读作 fa-una) (阴) 单三、六 ie; 常用单 - 动物群 [dong wù qún $]^{10}$

Słownik ten wydaje się użyteczną i podstawową skarbnicą wiedzy o języku polskim dla chińskiego studenta. Niestety, nie zawiera przykładów użycia danych wyrazów w zdaniach ani frazach, a do niektórych słów w języku polskim przypisanych jest kilka chińskich ekwiwalentów, które niekoniecznie pokrywają się z pierwotnym znaczeniem. Przykładowo do wyrazu 'śliczny' dopisane są: 极美的 (jimèi de), 非常漂亮的 (feècháng piàoliang de), 极好的 (ji hăo de), 质量好的 (zbiliàng băo de), które nie sa pojedynczymi wyrazami, lecz wyrażeniami, a ich znaczenie nie do końca koresponduje z hasłem wyjściowym. Układ haseł jest mało czytelny - transkrypcja w pinyin nie występuje zaraz po danym wyrazie ani też pod nim. Co zaskakujące, w przedmowie autorzy zaznaczaja, że chińskie znaczenia są zapisane tradycyjnymi znakami chińskimi, jednak w treści odnajdujemy zapis chiński uproszczony. Mimo wszystko należy docenić wkład autorów w przygotowanie słownika ze względu na obszerność i dokładność opisu gramatycznego. Mały stownik polsko-chiński niewątpliwie może służyć jako pomoc dydaktyczna chińskiemu studentowi uczącemu się języka polskiego. Natomiast użytkownik polski z pozycji tej wyniesie niewiele.

Podreczny stownik jesylka chińskiego został opracowany przez chiński zespół redakcyjny w 2010 r. i wydany przez pekińskie wydawnictwo Foreign Language Teaching and Research Press ${ }^{11}$. Należy podkreślić, że jest to słownik typu 字典 (zidiǎn) (pojedynczych znaków - morfemów leksykalnych), zawierający 800 znaków, których wyboru dokonano na podstawie analiz kwestionariuszy przeprowadzonych wśród

\footnotetext{
9 T. Jeromin, Din Wei, Mały stownik, polsko-chinski, Lódź 1990, ss. 471.

10 Ibidem, s. 76.

11 Xu Lin, Yao Xishuang, Podreczny stownikejesylea chińskiego, przeł. J. Szpakowska, Pekin 2010, ss. 536.
} 
pochodzących z różnych krajów studentów uczących się języka chińskiego w Chinach, jak również na podstawie kursów i innych słowników. Oprócz znaku zapisanego w formie uproszczonej i tradycyjnej oraz transkrypcji pinyin znajdującej się nad znakiem i polskiego odpowiednika (lub w niektórych przypadkach - definicji), zamieszczona jest również informacja o części mowy, przykłady złożeń danego znaku z innymi znakami tworzące nowe wyrazy, jak również przykładowe zdania. Przy niektórych hasłach możemy odnaleźć również informację gramatyczną. Poniżej przykład hasła z tego słownika ${ }^{12}$ :

\begin{tabular}{|c|c|}
\hline \multirow[t]{3}{*}{$\begin{array}{l}\text { pàng } \\
\text { 胖 }\end{array}$} & $\begin{array}{l}\text { praym. gruby: } \\
\text { pàng zi } \\
\text { 胖 子 } \\
\text { otyła osoba }\end{array}$ \\
\hline & $\begin{array}{l}\text { tā pàng le xǔ duō } \\
\text { 他 胖了 许 多。 } \\
\text { Bardzo przytył. }\end{array}$ \\
\hline & $\begin{array}{lll}\text { zhè ge xiǎo háir zhăng pàng le. } \\
\text { 这 个 小 孩儿 长 } & \text { 胖 } & \text { 了。 } \\
\text { Dziecko przytyło. } & & \\
& & \text { pàng } \\
& & \text { 胖 }\end{array}$ \\
\hline
\end{tabular}

Słownik skonstruowany jest w porządku alfabetycznym, jednak listy znajdujące się przed treścią właściwą umożliwiają wyszukiwanie haseł przy wykorzystaniu zapisu fonetycznego, liczby kresek lub klucza. W tekście głównym znajduje się również około 80 ilustracji oraz 8 stron kolorowych ilustracji z tyłu (sa to uporządkowane w kategorie rzeczowniki z życia codziennego). Słownik ten jest wydaniem kieszonkowym, wygodnym w użyciu. Jeśli chodzi o strukturę - układ i budowa haseł sa bardzo przejrzyste, a znaki są łatwe w wyszukiwaniu. Jednakże złożenia danych znaków wydaja się dobrane przypadkowo - przykładowo przy znaku 可 (kế) brakuje wyrazu 可以 (kèyl), który jest jednym z podstawowych i często używanych czasowników w języku chińskim. Opracowanie polskie pozostawia wiele do życzenia - liczne są literówki, a nawet błędy w tłumaczeniu (np. przy znaku 处 chù, niepoprawne tłumaczenie zdania 这是公园的管理处 zhè shì göngyuán de guănlüchü), zdania mieszają się z równoważnikami zdań i wydają się mało prototypowe. Słownik nie umożliwia wyszukiwania wyrazów polskich - działa jednostronnie. Nieuzasadnione

12 Ibidem, s. 242. 
wydają się też zamieszczone przy hasłach ilustracje, zwłaszcza że zazwyczaj wyrazy te nie wymagają dodatkowych uściśleń (np. kogut, spać czy księżyc).

Kolejnym opracowaniem poddanym analizie jest Stownik chińsko-polski wydawnictwa Edgar z 2012 r. $^{13}$, zawierający 10 tysięcy haseł uzupełnionych o złożenia, idiomy oraz przykłady użycia. Hasła również zostały uporządkowane alfabetycznie, dwukolumnowo, zgodnie z transkrypcją pinyin, a na początku słownika znajduje się wykaz kluczy oraz znaków (niestety, bez odnośnika do numeru strony). W słowniku można odszukać pojedynczy znak, który stanowi samodzielne hasło, jak również hasła wieloznakowe rozpoczynające się od danego znaku. Podstawowym zapisem jest chiński uproszczony, jednak w nawiasie podano też formę tradycyjną danego znaku. Poniżej zamieszczone zostało przykładowe hasło:

莫 mó 1. standard, norma

模 2. wzór; odwzorowywać

模范 ( 範) mófàn model, wzór; modelowy, wzorowy; ～的丈夫 ～de zhàngfu wzorowy mąż

模仿 mófăng naśladować; 一味 yīwèi ślepo naśladować

模糊 móhu niejasny, niewyraźny

模式 móshì wzór, wzorzec, model; 经营 jīngyíng model biznesowy

模型 móxíng 1. model 2. forma (odlewnicza) ${ }^{14}$.

Słownik ten jest prosty w użyciu, opracowany przejrzyście, na co wpływa również trafny dobór kroju czcionki. Co istotne, zawiera dużo użytecznych złożeń. Forma ich zapisu nie wydaje mi się jednak odpowiednia, ponieważ hasło właściwe zastapione jest tyldą. Użycie zmysłu wzroku ma kluczowe znaczenie w akwizycji chińskich znaków, całościowy zapis danego złożenia przyspieszyłby jego przyswojenie. Oczywiście rozumiem, że zabieg ten miał na celu zaoszczędzenie miejsca, jednak nie powinno się to odbywać kosztem okazji do szybszego zapamiętania danego znaku.

Stownik polsko-chinski, chinsko-polski wydawnictwa Level Trading z 2012 r. powstał na podstawie Stownika niemiecko-chińskiego, chinsko-niemieckiego z tej samej seri1 ${ }^{15}$. Jest podzielony na dwie części - polsko-chińską i chińsko-polska, zawiera około 14 tysięcy haseł uporządkowanych alfabetycznie zgodnie z alfabetem polskim w części pierwszej i transkrypcją pinyin w części drugiej. Terminy ułożone są w trzech kolumnach w następującej kolejności: polskie hasło, chińskie hasło w formie uproszczonej, zapis pinyin (w przypadku części pierwszej); chińskie hasło w formie uproszczonej, zapis pinyin, polskie hasło (w przypadku części drugiej). Nie są one opatrzone

13 K. Kocyba-Grych, Z. Kołecka, Stownik, chinsko-polski, Warszawa 2012, ss. 384.

${ }^{14}$ Ibidem, s. 214.

15 M. Dudzik, Stownik polsko-chiński, chinsko-polski, Czernica 2012, ss. 512. 
informacją gramatyczną, w słowniku nie występują również przykłady zdań ani użycia, co może stanowić problem dla użytkownika - słownictwo jest bowiem odcięte od kontekstu, jak w poniższym przykładzie.

aparat 机器 jiq $i$

aparat fotograficzny 照相机 ₹̧̧àoxiàngji $i^{16}$

Niestety, już na pierwszy rzut oka w hasłach można odnaleźć liczne błędy (przykładowo 高中毕业 - gāozhōng biyè przy haśle matura czy 咖啡色 - käfềisè przy brazomym), co czyni słownik mało wiarygodnym.

Na polskim rynku wydawniczym dostępne są również dwa słowniki tematycz$\mathrm{ne}^{17}$. Oba w moim przekonaniu zdecydowanie zasługują na uwagę ze względu na grupę docelową do której są skierowane: nie jest to jedynie użytkownik na poziomie podstawowym, jak w przypadku słowników opisanych powyżej. Słowniki te powstały z myślą o osobach poszukujących specjalistycznej wiedzy z różnych dziedzin.

Polsko-chinski stownik tematyczny autorstwa Chai Hongyun, He Qingzhen i Iwony Jackowskiej został wydany przez Pol-Chin Consulting w 2010 r. Znajduje się w nim około 18 tysięcy haseł (zarówno słów, jak i wyrażeń) podzielonych na 27 kategorii głównych i 144 podkategorie. Słownictwo jest uporządkowane tematycznie, zawiera leksykę ogólną, potoczną, jak również specjalistyczną - większość haseł to rzeczowniki. Autorzy zaznaczaja, że słownik ten jest przeznaczony przede wszystkim do nauki języka chińskiego i polskiego skoncentrowanej na konkretnej dziedzinie oraz do wykorzystania przy tłumaczeniach polsko-chińskich. Hasła są uszeregowane w następującej kolejności: hasło w języku polskim, hasło w języku chińskim (znaki uproszczone), transkrypcja pinyin. Ułożone są na zasadzie logicznej kategoryzacji (z pominięciem układu alfabetycznego), np. przy słownictwie dotyczącym ludzkiego ciała słowa omawiane są od części górnych do części dolnych. Przykładowy segment tematyczny zawarty w omawianym słowniku wygląda następująco ${ }^{18}$ :

\begin{tabular}{|c|c|c|}
\hline sznurówka & 鞋带 & xié dài \\
\hline dziurka & 鞋眼儿 & xié yǎnr \\
\hline język & 鞋舌面 & xié shé miàn \\
\hline cholewa & 鞋面 & xié miàn \\
\hline podeszwa & 鞋底 & xié dĩ \\
\hline obcas & 鞋跟 & xié gēn \\
\hline
\end{tabular}

\footnotetext{
16 Ibidem, s. 17.

17 Chai Hongyun, He Qingzhen, Iwona Jackowska, Polsko-chiński stownik tematyczny, Warszawa 2010, ss. 774; Yin Xiangfeng et al., Chińsko-polski stownik tematyczny, Pekin 2013, ss. 700.

18 Chai Hongyun, He Qingzhen, Iwona Jackowska, Polsko-chiński stownik..., s. 273.
} 


\begin{tabular}{|c|c|c|}
\hline łyżka do butów & 鞋拔 & xié bá \\
\hline pasta do butów & 鞋油 & xié yóu \\
\hline szczotka do butów & 鞋刷 & xié shuā \\
\hline szewc & 鞋匠 & xié jiàng \\
\hline
\end{tabular}

Jeśli chodzi o kwestie warte dopracowania, to samo opracowanie redakcyjne wymagałoby rzetelniejszej korekty, gdyż pojawiają się literówki, oraz rozwiązania pewnych problemów związanych z kategoryzacją (np. chipsy usytuowano w sekcji czekolada). Nie ma również konsekwencji w hasłach polskich - zdania są zapisywane raz w cudzysłowie, raz bez, a w wyrażeniach czasowniki nie mają ujednoliconej formy (bezokolicznik/forma odmieniona). Znaczącym mankamentem jest brak indeksu, który ułatwiłby wyszukanie konkretnych słów.

Z kolei Chinsko-polski stownik tematyczny wydany w 2013 r. przez The Commercial Press z siedzibą w Pekinie zawiera 25 tysięcy haseł z pięciu dziedzin: życie codzienne, życie społeczne, sprawy publiczne, działalność gospodarcza, nauki społeczne i przyrodnicze. Jest to zatem najobszerniejszy dostępny słownik w tej parze językowej. Został podzielony na 44 podrozdziały, a ułożone tematycznie hasła uporządkowano od ogólnych do specjalistycznych i usytuowano w dwóch kolumnach. Występują one w następującej kolejności: hasło chińskie (w zapisie uproszczonym, znajdujące się w nawiasie kwadratowym), transkrypcja pinyin oraz polskie tłumaczenie, co widać na poniższym przykładzie ilustrującym pojedynczy segment tematyczny.

\section{- 眼镜}

【眼镜】yǎnjìng okulary

【平光镜】 píngguāngjìng okulary zerówki

【隐形眼镜片】 yǐnxíng yǎnjìng pian soczewka kontaktowa

【隐形眼镜水】y̌nxíng yǎnjìngshuǐ płyn do soczewek kontaktowych

【墨镜】mòjìng okulary przeciwsłoneczne

【变色眼镜】biànsè yǎnjìng okulary zmieniające kolor

【夹鼻镜】jiābijìng binokle

【风镜】 fēngjìng okulary ochronne

【立体镜】 litijìng stereoskop

【3D眼镜】3D yǎnjìng okulary $3 \mathrm{D}^{19}$

Wyszukiwanie haseł jest ułatwione dzięki zamieszczonemu na końcu słownika indeksowi alfabetycznemu (w znakach), odsyłającemu do strony, na której dane hasło występuje. Z informacji zawartych w przedmowie wynika, że słownik ten powstał w ramach projektu realizowanego w 18 parach językowych, a tego typu

19 Yin Xiangfeng et al., Chińsko-polski stownik..., s. 57. 
opracowania mają ogromne znaczenie dla rozwoju stosunków kulturowych i gospodarczych, są również narzędziami chińskiego soft power. Okoliczności przygotowania słownika jako jednej z wersji językowych na równi z kilkunastoma innymi parami językowymi wpłynęły na zawartość haseł, co przełożyło się na brak m.in. typowego słownictwa związanego z Polska, czym wyróżnia się wspomniany wyżej Polsko-chinski stownik tematyczny. Mimo to w mojej ocenie wydany przez The Commercial Press Chińsko-polski stownik tematyczny zasługuje na najwyższe uznanie. Można znaleźć w nim specjalistyczne słownictwo niedostępne w innych źródłach, a zapis jest czytelny i przejrzysty. Nie należy oczekiwać, aby w słowniku tematycznym znajdowały się przykładowe zastosowania danych wyrazów - zarówno ta pozycja, jak i poprzednia ich nie zawiera.

W ostatnim czasie pojawiły się dwa słowniki wydawnictwa Bohan, których autorami są Marlena Achinger i Antoni Radziwiłł. Pierwszym z nich jest Polsko-chinski, chinsko-polski stownik biznesony z 2015 r. ${ }^{20}$, którego celem było zapełnienie luki zwiazanej z chińską leksykografią biznesową na rynku polskim. W słowniku znajduje się 8 tysięcy ułożonych alfabetycznie haseł specjalistycznych związanych z biznesem, handlem, zarządzaniem, finansami oraz logistyką. Słownik jest podzielony na dwie części - polsko-chińską oraz chińsko-polską, a każde z haseł składa się z tłumaczenia, transkrypcji pinyin, zapisu znakami w formie uproszczonej (w części drugiej również w tradycyjnej) oraz informacji o części mowy, jak w poniższym przykładzie.

零售商 [零售商] /língshòu shang/ ( r zec\%/名) detalista 这家公司是中国最大的 手机零售商。Ta firma jest najwiekssym w Chinach detalista telefonón komórkowych ${ }^{21}$.

Dużym atutem tego słownika jest dobór terminologii ściśle związanej z polskim rynkiem oraz przykładowe zdania do (niestety tylko) niektórych haseł. Przeszkoda w odbiorze treści może być zastosowana w znakach chińskich kursywa, która utrudnia ich odczytywanie ${ }^{22}$. Jednak mimo drobnych zastrzeżeń słownik jest skonstruowany w przejrzysty sposób i może być przydatnym narzędziem do pracy i nauki dla osób zainteresowanych tą konkretną tematyką.

Druga z pozycji opracowanych przez wydawnictwo Bohan jest Stownik $H S K^{23}$, który zawiera 5 tysięcy słów i zwrotów wymaganych przy przystępowaniu do państwowego egzaminu znajomości języka chińskiego HSK (Hanyu Shuiping Kaoshi 汉语水平考试). To jedyna tego typu pozycja na rynku polskim, skierowana przede wszystkim do osób przygotowujących się do tegoż egzaminu. Autorzy zaznaczaja, że ich misją w przygotowaniu tego słownika było zwiększenie liczby osób zainte-

20 M. Achinger, A. Radziwiłł, Polsko-chiński, chinsko-polski stownik biznesowy, Kęty 2015, ss. 450.

21 Ibidem, s. 325.

${ }^{22}$ Zgodnie z przyjęta konwencją w tekście drukowanym znaków chińskich nie zapisuje się kursywą.

23 M. Achinger, A. Radziwiłł, Stownik HSK. Hanyu Shuiping Kaoshi, Kęty 2017, ss. 531. 
resowanych współpracą z Państwem Środka. Słownik został podzielony na sześć części odpowiadających poziomom HSK, dzięki czemu użytkownik może w szybki i łatwy sposób znaleźć interesujące go słownictwo. Struktura haseł słownikowych wygląda podobnie jak w wyżej omawianej pozycji tego wydawnictwa - słowo chińskie (w formie uproszczonej), transkrypcja pinyin oraz znaczenia danego słowa w języku polskim z adnotacją dotyczącą części mowy. Do każdego hasła dopisane są dwa przykłady użycia w języku chińskim wraz z polskim tłumaczeniem, dzięki czemu użytkownik poznaje kontekst, do którego dane słowo jest najczęściej wykorzystywane. Budowę hasła słownikowego ilustruje poniższy przykład.

偏见/piānjiàn/ (rzecz./名) uprzedzenie: 我对外籍员工没有偏见。Nie mam żadnych uprzedzeń wobec zagranicznych pracowników. | 我对种族偏见深恶痛绝! Nie cierpię uprzedzeń rasowych! ${ }^{24}$

Słownik ten stanowi kompendium leksykalnej wiedzy potrzebnej do egzaminu HSK, przykładowe zdania sa prototypowe, a czytelna, logiczna i alfabetyczna budowa słownika sprawia, że wyszukiwanie haseł jest szybkie i łatwe. W opracowaniu polskim znajdują się jednak drobne błędy stylistyczne i interpunkcyjne oraz literówki. Niektóre z haseł wymagałyby doprecyzowanego tłumaczenia, czyli dodatkowych informacji natury pozajęzykowej, które nie wprowadzałyby w błąd (np. przy haśle 预习 - yùxi podany jest polski odpowiednik 'przygotowywać się', co powinno być opatrzone komentarzem autora - znaczenie słowa 预习 - yùxí wiąże się tylko i wyłącznie z czynnościa prazygotonywania w odniesieniu do lekcji, która nie została jeszcze przeprowadzona). Pozycja ta jest bardzo wartościowa z punktu widzenia osób uczących się i jeśli autorzy uwzględnią drobne uwagi przy kolejnym wydaniu, może on stać się słownikiem rekomendowanym przez dydaktyków.

Omawiając pozycje wydane przez wydawnictwo Bohan, nie sposób nie wspomnieć o ciekawych pozycjach leksykograficznych - zawierającym około 600 haseł Stowniku ślasko-chinskim autorstwa Marka Jachymskiego z 2011 r. oraz nieco obszerniejszym (2600 haseł) Kaszë̈bskò-chinsczị chińskò-kaszëbsczi stowôrz. (czyli Stowniku kaszubsko-chińskim, chińsko-kaszubskim) opracowanym przez Krzysztofa Achingera w 2018 r. Według autorów nie są to jednak narzędzia do faktycznej pracy, a raczej do wzajemnej promocji regionów i języków. Muszę przyznać, że inicjatywa ta jest imponująca, a twórcom należą się wyrazy uznania - przede wszystkim za trud włożony w tak niekonwencjonalny projekt.

Oprócz opisanych wyżej słowników na rynku polskim znajdują się również trzy pozycje obrazkowe, z czego jedna jest skierowana bezpośrednio do dzieci. 1000 chinskich stów(ek) - ilustrowany stownik chinsko-polski, polsko-chinski to publikacja wydana w 2012 r. przez Albatros Media i Level Trading w przyjemnej dla oka szacie

${ }^{24}$ Ibidem, s. 415. 
graficznej ${ }^{25}$. Słownik jest podzielony na bloki tematyczne, a każdy z nich wzbogacono rysunkami wraz z chińskimi słowami, transkrypcja pinyin oraz polskim tłumaczeniem. Oprócz tego po głównych działach tematycznych zamieszczono przydatne zwroty (w formie często występującej w publikacjach typu „rozmówki”). Na końcu słownika możemy odnaleźć alfabetyczny indeks zarówno w konfiguracji polsko-chińskiej, jak i chińsko-polskiej. Nie zawiera on jednak elementów związanych typowo z kulturą chińska, które powinno się przyswajać w procesie nauki języka, słowniki o tej samej budowie i w tej samej formie zostały stworzone w dwunastu językach.

Wspomniane wcześniej wydawnictwo The Commercial Press w 2009 r. opublikowało polską wersję Obrazkowego stowničkea jesylka cbińskiego26, a rok później - Obrazkowego stownika jesylka chińskiego ${ }^{27}$. Pierwszy z nich skierowany jest do młodszych odbiorców - zawiera około 1400 haseł podzielonych na 70 rozdziałów tematycznych - struktura podobna jest do struktury wcześniejszej pozycji: ilustracja, hasło chińskie, transkrypcja pinyin oraz polskie tłumaczenie. Innowacyjnym rozwiazaniem jest dołączenie do tej pozycji elektronicznego długopisu odczytującego hasła w jezyku polskim i chińskim - rozwiazanie to pozwala na naukę poprawnej wymowy bez pomocy nauczyciela. Na każdej stronie znajduja się ćwiczenia sprawdzające opanowane słowa, a polecenia do nich sa wydawane przez długopis. To wszystko sprawia, że omawiany słownik przypomina bardziej podręcznik niż typowa pozycję leksykograficzną.

Za najlepsze i najobszerniejsze opracowanie ilustrowane uznaję Obrąloony stownike jezyka chińskiego $2^{28}$, zawierający 4200 słów podzielonych na 15 podrozdziałów, w ramach których łącznie wyodrębniono 142 tematy, dotyczące różnego rodzaju aspektów życia codziennego. Słownik został zredagowany zgodnie z Powszechnym Międzynarodowym Programem Dydaktyki Języka Chińskiego opracowanym przez Chińskie Państwowe Biuro Międzynarodowej Promocji Języka Chińskiego (Hanban) w bardzo estetyczny i dokładny sposób. Układ haseł jest podobny do wcześniej omawianych pozycji - przy obrazkach znajdują się numery, które odnoszą do danego znaczenia występującego w formie znaków i transkrypcji pinyin. Pod chińskimi wyrazami znajduje się polski odpowiednik. Tłumaczenia są adekwatne, rzetelne i spójne, a słownictwo bogate i przedstawione w ciekawy sposób. Autorzy zaznaczają że przy konstruowaniu słownika uwzględnili pluralizm kulturowy, dlatego leksyka w nim zawarta nawiązuje zarówno do azjatyckiej, jak i zachodniej kultury. Na końcu słownika znajdują się dwa uszeregowane alfabetycznie indeksy wyrazów - pierwszy w języku chińskim, drugi w języku polskim. Pomimo że hasła w tekście głównym są zapisane w znakach uproszczonych, w indeksie możemy odnaleźć ich

251000 chinskich stów(ek) - ilustrowany stownik chinsko-polski, polsko-chinski, oprac. zbiorowe, Czernica 2012, ss. 152.

26 Wu Yuemei, Obrazkowy stowniczek, jesyka chinskiego, Pekin 2009, ss. 175.

27 Wu Yuemei, Obrazkony stownik, jezylka chińskiego, Pekin 2010, ss. 349.

28 Ibidem. 
formy tradycyjne. Pozycja ta, traktowana jako rodzaj słownika obrazkowego, całkowicie spełnia swoją funkcję. Niesprawiedliwe wobec twórców byłoby więc doszukiwanie się jej wad.

Mimo prężnie rozwijającej się leksykografii polsko-chińskiej na rynku wciąż brakuje pozycji, która zadowoliłaby tłumaczy lub inne osoby w lepszym stopniu władające językiem chińskim. Czerpiąc wiedzę z doświadczenia i relacji sinologów, można wywnioskować, że podstawą dla pracy z językiem i zaawansowanej już nauki pozostaja słowniki anglojęzyczne, szczególnie te dostępne w formie aplikacji na telefon. Wybór ten jest spowodowany ograniczoną i podstawową leksyką ujmowaną w pozycjach polsko-chińskich i chińsko-polskich - najobszerniejsze opracowanie zawiera tylko 25 tysięcy haseł (dla porównania losowo przywołany w tym miejscu Podreczny stownik polsko-angielski wydany w 2003 r. przez wydawnictwo Wiedza Powszechna zawiera ich 120 tysięcy).

Ponadto użytkownicy podważają wiarygodność ekwiwalentów zawartych w niektórych pozycjach polskojęzycznych oraz skarżą się na brak odpowiednich przykładów użycia. Co więcej, z punktu widzenia użytkownika rozpoczynającego naukę lub będącego na poziomie podstawowym wiele słowników oferowanych na polskim rynku wydawniczym nie daje pełnego obrazu języka i kultury chińskiej, ponieważ wiedza, która z nich czerpią, jest powierzchowna. Z powodu niedbałej lub niedokładnej korekty materiału w niektórych pozycjach pojawiły się nawet niepoprawne ekwiwalenty, co naraża uczących się na ryzyko fosylizacji i utrwalenia błędów językowych. Istotę tego problemu można podsumować słowami samego Konfucjusza: „Jeżeli nazwy nie sa poprawne, słowa nie odpowiadają prawdzie"29. Jednakowoż nie ulega wątpliwości, że na rynku zaczynają się pojawiać opracowania, które spełniaja potrzeby niektórych grup docelowych, np. Stownik HSK jako kompendium wiedzy potrzebnej do zdania oficjalnego egzaminu z języka chińskiego, Chinsko-polski stownik tematyczny z nieco bardziej rozbudowaną leksyką specjalistyczną czy też Obrazkowy stownik jezyka chińskiego jako opracowane w niezwykle rzetelny sposób narzędzie do nauki języka z użyciem estetycznych ilustracji.

Przechodząc do wniosków płynących z powyższego omówienia, warto zastanowić się, co można by udoskonalić w dalszych pracach nad chińsko-polskimi opracowaniami leksykograficznymi. Polski użytkownik potrzebuje przede wszystkim słownika wiarygodnego (!), o przejrzystej budowie, przekazującego wiedzę o języku w całościowy i niepowierzchowny sposób. Z powodu olbrzymiej różnicy między polskimi $i$ chińskimi systemami językowymi i kulturowymi istnieje również potrzeba zamieszczania w pozycjach słownikowych zdań prototypowych, które przybliżyłyby użytkowników do poznania dogłębnego znaczenia danego wyrazu.

29 E. Skalińska, Chiński Norwid a myśl i poetyka norwidologii polskiej. Recenæja ksiażki Krayssztofa Andrzeja Jeżenskiego 'Cyprian Norwid a myśl i poetyka Kraju Środka', „Colloquia Litteraria” 2014, nr 2, s. 72. 
Ponadto warto byłoby przy hasłach nieoczywistych dodawać krótką notkę definiująca - wyjaśnienie nieścisłości związanych ze znaczeniem lub użyciem danych słów jest kluczowe dla poprawnej akwizycji języka. Zgadzam się zatem z opinią Bożeny Ostromęckiej-Frączak, która twierdzi, że dobry słownik dwujęzyczny nie może opierać się tylko na ekwiwalentach, a zadaniem leksykografa jest „opis znaczenia jako bytu i jako umiejętności jego użycia" ${ }^{30}$. Do tego właśnie winni dążyć leksykografowie zajmujący się słownikami opracowywanymi w relacji chińsko-polskiej, które powinny pełnić zarówno funkcję przewodników w zakresie poprawności językowej i obopólnych znaczeń, jak i pośredników, „mostów” międzykulturowych.

Należy pamiętać również o tym, że słownik ma być łatwy i wygodny w użyciu, umożliwiać szybkie wyszukiwanie ekwiwalentu pożądanego wyrazu czy znaku. Warto popracować nad rozwojem, aktualizacją i podniesieniem efektywności aplikacji mobilnych oraz pozycji online, które współcześnie coraz częściej zastępują słowniki w tradycyjnej formie papierowej. W moim przekonaniu każdy sinolog, polonista lub inny ekspert zajmujący się leksykografią polsko-chińską powinien stawiać sobie za cel oddanie jak najbardziej zbliżonego do rzeczywistości językowego i kulturowego obrazu świata Polaków i Chińczyków, który przejawiałby się we wszystkich znakach, słowach, znaczeniach, ekwiwalentach znajdujących się w opracowywanej pozycji.

\section{SUMMARY}

\section{ON CHINESE-POLISH LEXICOGRAPHY}

Lexicography is a branch of science that involves both the practice and the theory of building up dictionaries. Bilingual dictionaries play a significant role in intercultural communication, foreign language acquisition and learning. Since the economic, cultural and strategic relations between Poland and China are strengthening, and Chinese Studies are becoming increasingly popular among Polish people, the issue of Chinese-Polish lexicography is becoming a matter of great importance. This paper aims at setting out problems connected with creating dictionaries in the aforementioned language pair. The author describes, analyses and evaluates both Chinese-Polish and Polish-Chinese dictionaries, which are available on the publishing market. The article attempts to answer the question whether the existing dictionaries meet the expectations of the users and what kind of information should be contained in a good dictionary. The research shows that there is still need for further development of Chinese-Polish lexicography, particularly with regard to those dedicated for the advanced Chinese language learners and translators. It also reveals the problem of semantic equivalence and its appropriateness in the dictionaries.

30 B. Ostromęcka-Frączak, Stownik dwujesyczny i jego rola w nauczaniu jezy/ka polskiego, „Acta Universitatis Lodziensis. Kształcenie Polonistyczne Cudzoziemców” 1998, t. 10, s. 390-391. 